\title{
ON THE RESULTS
}

OF TEP

\section{TREATMENT OF PULMONARY CONSUMPTION BY RESIDENCE AT HIGH ALTITODES,}

AS EXEMPLIFIED BY AN ANALYSIS OF 141 CASES.

BY

C. THEODORE WILLIAMS, M.A., M.D., F.R.C.P., PHYgICIAN TO THE HOBPITAI FOR CONGUMPTION AND DIBBAgES OF THB CHEST, BROMPTON.

Received January 10th-Read May 8th, 1888.

TeE treatment of phthisis by residence at high altitudes, though extensively used by Drs. Archibald Smith, Guilbert, Lombard, Jourdanet, Brehmer and others, was first brought to the notice of this Society by Dr. Hermann Weber in an admirable paper to be found in vol. lii of the 'Transactions,' to which all workers on the effects of climates are much indebted, not only for the able discussion of the objections raised to Alpine climates, but also for the valuable record of seventeen cases of phthisis treated by residence at high altitudes in different parts of the world.

Since then a number of papers and works have appeared on the same subject contributed by Drs. Clifford Allbutt, 
Spengler, McCall Anderson, Symes Thompson, Tucker Wise, Burney Yeo, Lindsay, and others, dealing for the most part with the climate of Davos and the Engadine and with the life of the invalid in these localities, but since the publication of Dr. Weber's cases we have had but few clinical illustrations of the effects of this climate on consumptives and still fewer statistics, the principal ones being Dr. Denison's ${ }^{1}$ cases of consumption treated in Colorado.

Having made the acquaintance of Davosand the Engadine in 1862, I revisited these places in 1872 , with the view of using them as summer and winter health resorts for English consumptives, but it was not until 1878 that the opening of an hotel specially arranged for English people, and the presence of an English-speaking doctor at Davos, enabled me to carry out my intentions to any extent. Since then St. Moritz, Wiesen and the Maloja have also been rendered available for the reception of patients in winter as well as in summer, and have been utilised by myself and others.

The object of this paper is to give a statistical account of 141 consumptive patients, who have lived for periods extending from months to years in high-lying localities, varying in altitude from 5000 to $9000 \mathrm{ft}$., either in Switzerland or in Colorado (Rocky Mountains), or in the South African Highlands, and to deduce from their histories and their results the kind of case most likely to benefit, and also that most likely to be injured, by this method of treatment; moreover, to draw up such practical rules as will render the climatic sojourn as useful and beneficial as possible.

I may remind the Fellows of the Society that this is the third series of statistics bearing on the climatic treatment of consumption offered by me to the profession, the first being a paper on the "Effects of Warm Climates in the Treatment of Pulmonary Consumption," as exemplified in $\mathbf{2 5 1}$ cases, contained in vol. Iv of the 
'Medico-Chirurgical Transactions;' the second, on the effects of the British South Coast and other home climates on 243 consumptives, was published in the Lettsomian Lectures for 1876, and it is hoped that a comparison between these and the present cases may afford the means of judging to some extent of the relative advantages and peculiarities of each form of climatic treatment. Of the present 141 cases 6 were published in the 'Lancet' of 1879, after my third visit to Davos, and 16 more were contained in a paper read at the International Medical Congress held in London in 1881, and included in the 'Transactions' of that meeting. Three cases more were contributed to vol. xvi of the 'Clinical Society's Transactions,' making in all 25 which have been published before in some form or other. The remaining 116 are now presented to the Society, and together with the first 25, they form a number from which conclusions with reference to high-altitude treatment may safely be drawn. The cases are too numerous to give in full, and I have therefore tabulated them under the following headings:

Sex.

Age.

State at first visit.

Nature and extent of disease.

Length of illness.

Family predisposition.

Hæmoptysis.

Length of residence at high altitudes.

Results $\left\{\begin{array}{l}\text { General. } \\ \text { Weight. } \\ \text { Local. } \\ \text { Chest circumference. }\end{array}\right.$

Remarks, including history up to date or death.

A specimen of such a table is shown. 


\begin{tabular}{|c|c|c|c|c|c|c|c|c|c|}
\hline No. & Name. & Sex. & Age. & $\begin{array}{l}\text { Date of } \\
\text { lst visit. }\end{array}$ & $\begin{array}{l}\text { Nature and extent of } \\
\text { disease. }\end{array}$ & $\begin{array}{l}\text { Length } \\
\text { of } \\
\text { illness. }\end{array}$ & $\underset{\text { predisposition. }}{\text { Family }}$ & $\begin{array}{l}\text { Hæmo- } \\
\text { ptysis. }\end{array}$ & $\begin{array}{l}\text { Length of } \\
\text { residence. }\end{array}$ \\
\hline 101 & Mr. S. & M. & 25 & May 8, '85 & $\begin{array}{l}\text { Phth.I-III. Pigeon-breasted; } \\
\text { softening of right upper lobe, } \\
\text { and rheumatic fever fre- } \\
\text { quently; mitral disease (re- } \\
\text { gurgitant); syphilis. }\end{array}$ & $\begin{array}{c}\text { About } \\
4 \text { years. } \\
\text { Bacilli } \\
\text { present }\end{array}$ & Mother d. phth. & $5 \mathrm{oz}$. & $\begin{array}{l}\text { St. Moritz } \\
2 \text { winters, } \\
\text { Davos } \\
1 \text { summer. }\end{array}$ \\
\hline 102 & Mr. H. & M. & 45 & June 18,'85 & $\begin{array}{l}\text { Phth. I. Consolidation, of } \\
\text { both apices; syphilis. }\end{array}$ & 1 year & None & $\begin{array}{c}\text { Large } \\
\text { amount } \\
\text { on several }\end{array}$ & $\begin{array}{l}\text { Wiesen } \\
10 \\
\text { months. }\end{array}$ \\
\hline 108 & Miss K. & F. & 20 & Sept. 22,'85 & $\begin{array}{l}\text { Phth. III. Cavity in upper left } \\
\text { lobe; consolidation of lower } \\
\text { lobe. }\end{array}$ & - & Mother d. phth. & $\begin{array}{c}\text { occusions } \\
\text { None }\end{array}$ & $\underset{4 \text { months }}{\text { Davos }}$ \\
\hline 104 & $\begin{array}{l}\text { Rev. J. } \\
\text { C. } \mathbf{M} \text {. }\end{array}$ & M. & 28 & Aug. 20,'85 & $\begin{array}{l}\text { Phth. II. Hæmorrhagic soften. } \\
\text { ing upper right lobe, with } \\
\text { hæmorrhagic consolidation } \\
\text { lower right. }\end{array}$ & $\begin{array}{c}6 \text { weeks. } \\
\text { Bacilli } \\
\text { abund- } \\
\text { ant. }\end{array}$ & $\begin{array}{l}\text { Sister and } \\
\text { paternal aunt } \\
\text { and uncle d. } \\
\text { phth. }\end{array}$ & $\begin{array}{l}10 \mathrm{oz} . \\
\text { several } \\
\text { times. }\end{array}$ & $\begin{array}{c}\text { Davos } \\
2 \text { years, } \\
\text { Pontre- } \\
\text { sina }\end{array}$ \\
\hline 105 & $\begin{array}{l}\text { Mrs. F. } \\
\text { M. }\end{array}$ & F. & 30 & Aug. 15, '85 & $\begin{array}{l}\text { Phth. I. Tuberculisation upper } \\
\text { right lobe. }\end{array}$ & 6 months & - & None & $\begin{array}{l}1 \text { summer } \\
\text { St. Moritz } \\
6 \text { mouths }\end{array}$ \\
\hline 106 & Mr. M. & M. & 22 & Sept.23, '85 & $\begin{array}{l}\text { Phth. III. Scattered cavities in } \\
\text { in right lung. }\end{array}$ & $\begin{array}{c}18 \text { mos. } \\
\text { Bacilli } \\
\text { few. }\end{array}$ & - & Some & $\begin{array}{l}\text { St. Moritz } \\
2 \text { winters }\end{array}$ \\
\hline 107 & Mr. C. & M. & 20 & Sept. 8, '85 & $\begin{array}{l}\text { Phth. I. Tuberculisation, both } \\
\text { upper lobes. }\end{array}$ & $\begin{array}{l}7 \text { years. } \\
\text { Bacilli }\end{array}$ & $\begin{array}{c}\text { Father and } \\
\text { brother d.phth. }\end{array}$ & None & $\begin{array}{l}\text { St. Moritz } \\
6 \text { months }\end{array}$ \\
\hline 108 & Mr. L. & M. & 34 & Aug. 28, '85 & $\begin{array}{l}\text { Phth. I. Tuberculisation, both } \\
\text { upper lobes. }\end{array}$ & $\begin{array}{l}\text { present. } \\
9 \text { mos., } \\
\text { winter } \\
\text { cough }\end{array}$ & None & $\begin{array}{l}\text { loz. } \\
\text { several } \\
\text { times }\end{array}$ & $\begin{array}{l}\text { St. Moritz } \\
6 \text { months }\end{array}$ \\
\hline 109 & Sir A. N. & M. & 30 & June 24,'85 & $\begin{array}{l}\text { Phth. 1. Tuberculisation of } \\
\text { upper half of left lung. }\end{array}$ & $\begin{array}{l}10 \text { years. } \\
3 \text { years. }\end{array}$ & $\begin{array}{l}\text { Paternal uncle } \\
\text { d. phth. }\end{array}$ & None & $\begin{array}{l}\text { St. Moritz } \\
1 \text { winter }\end{array}$ \\
\hline 110 & Mr.C.E. & M. & 26 & July 23, '85 & $\begin{array}{l}\text { Phth. III. Contracting cavity } \\
\text { in left lung; tuberculisation } \\
\text { in upper left lobe. }\end{array}$ & $\begin{array}{c}5 \text { years. } \\
\text { Bacilli } \\
\text { abund- }\end{array}$ & Mother d. phth. & None & $\begin{array}{c}\text { Daros } \\
6 \text { months }\end{array}$ \\
\hline 111 & Mr. R. & M. & 34 & Aug. 25, '85 & $\begin{array}{l}\text { Phth. I. Tuberculisation of both } \\
\text { upper lobes; fistula } 6 \text { months. }\end{array}$ & $\begin{array}{c}\text { ant. } \\
1 \text { year. } \\
\text { Bacilli } \\
\text { present. }\end{array}$ & None & Bome & $\begin{array}{c}\text { Davos } \\
2 \text { years }\end{array}$ \\
\hline 112 & Miss G. & F. & 28 & May 27, '85 & $\begin{array}{l}\text { Phth.I. Tuberculisation exten- } \\
\text { sive in right lung and in } \\
\text { upper lobe of left. }\end{array}$ & $\begin{array}{c}3 \frac{1}{2} \text { years. } \\
\text { Bacilli } \\
\text { abund- }\end{array}$ & - & None & $\begin{array}{c}\text { Davos } \\
6 \text { months }\end{array}$ \\
\hline 113 & Mr. F. & M. & 29 & Oct. 2, '85 & $\begin{array}{l}\text { Phth. III. Cavity in right lung } \\
\text { (middle lobe); tuberculssa- } \\
\text { tion of upper left lobe; mor- } \\
\text { bus cordis (aortic disease); } \\
\text { occasional pyrexia. }\end{array}$ & $\begin{array}{c}\text { ant. } \\
1 \text { year. } \\
\text { Bacilli } \\
\text { present. }\end{array}$ & None & $\begin{array}{l}\text { Streaked } \\
\text { expectora- } \\
\text { tion }\end{array}$ & $\begin{array}{l}\text { St. Moritz } \\
2 \text { winters }\end{array}$ \\
\hline 114 & Mr. I. & M. & 20 & Mar.15, '86 & $\begin{array}{l}\text { Phth.III. Cavity of left lung; } \\
\text { syphilis. }\end{array}$ & $\begin{array}{l}1 \text { year. } \\
\text { Bacilli } \\
\text { abund- }\end{array}$ & $\begin{array}{l}\text { Father, mother, } \\
\text { and paternal } \\
\text { uncles d. phth. }\end{array}$ & None & $\underset{8 \text { months }}{\text { Davos }}$ \\
\hline 115 & Miss S. & F. & 27 & Nov. 11, ' 85 & $\begin{array}{l}\text { Phth. I. Tuberculisation } \\
\text { upper right lobe. }\end{array}$ & 6 weeks. & $\begin{array}{l}\text { Brotherd.acute } \\
\text { phth., father d. }\end{array}$ & None & $\begin{array}{c}\text { Davos } \\
2 \text { winters }\end{array}$ \\
\hline 116 & R८V.J.M. & $\mathbf{M}$. & 38 & Oct. 9, '85 & $\begin{array}{l}\text { Phth. I-III. Softening and } \\
\text { tuberculisation both proceed- } \\
\text { ing in left upper lobe. }\end{array}$ & 4 months & $\begin{array}{l}\text { phth. } \\
\text { None }\end{array}$ & None & $\begin{array}{c}\text { Davos } \\
2 \text { winters }\end{array}$ \\
\hline
\end{tabular}




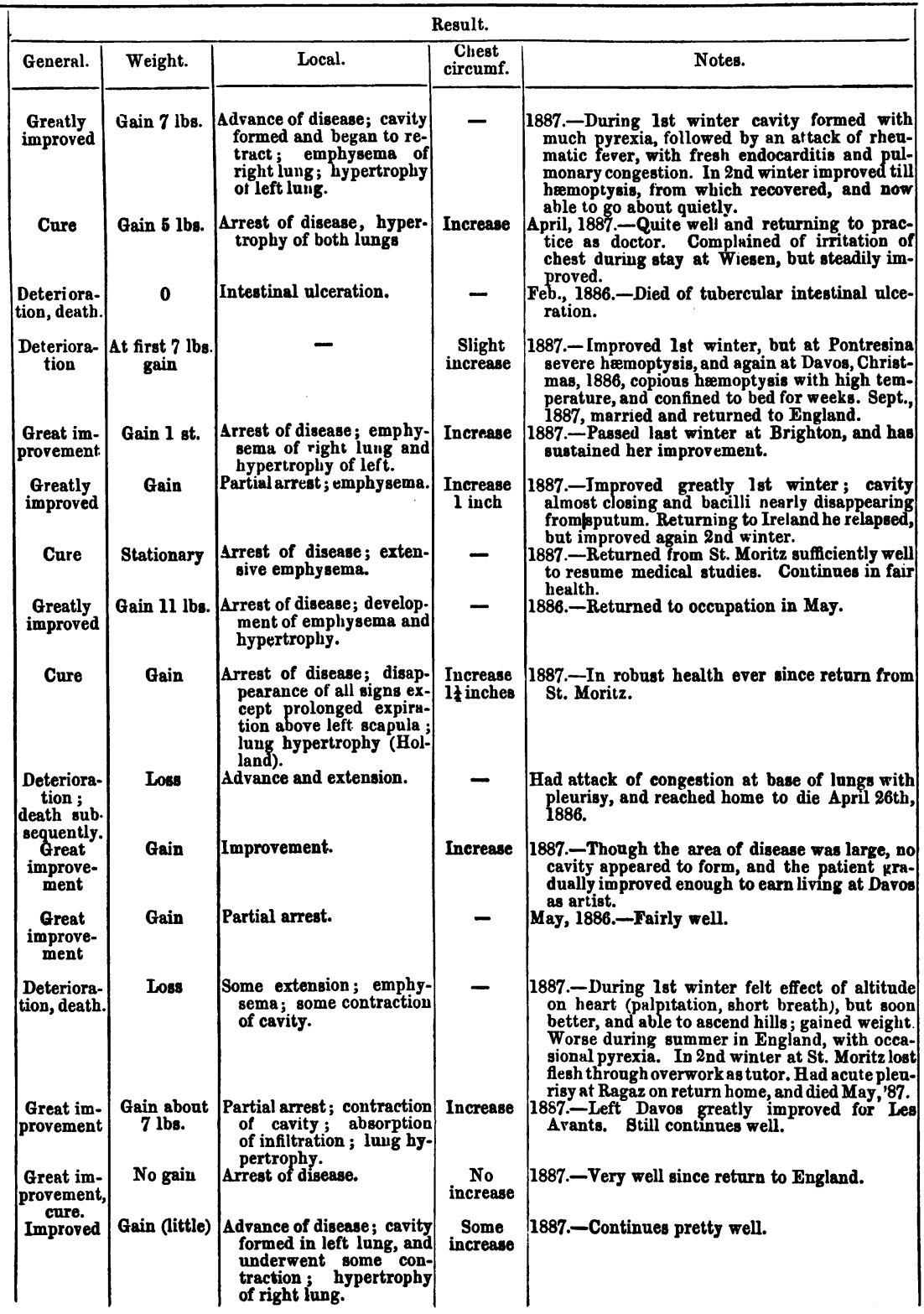


Two cases are furnished in full as examples.

CASE 1.-Miss K-, æt. 17, seen August 15th, 1884, with a history of cough, expectoration, night sweats, and loss of flesh since February last, the loss of weight amounting to seven pounds. Breath short on exertion. The physical signs were, right side, flattening and crepitation in first intercostal space; left side, crepitation in first intercostal space. Weight 8 st. 8 lbs.

Ordered cod-liver oil with hyophosphite of lime and counter-irritation to both sides of chest.

September 20th.-Cough worse, expectoration contains numerous tubercle bacilli. Oavernous sounds audible in first and second spaces on right side and over the upper fourth posteriorly. On left side crepitation heard above the clavicle, as well as in first space. Chest measurements at level of second rib, right fifteen and a half inches; left fifteen and a half inches. Ordered to winter at St. Moritz under the care of Dr. Holland.

Miss K- went to St. Moritz in October, and at first the cough and expectoration increased and she had some pyrexia, which yielded to antipyrin and good nursing. She steadily improved and was able to take moderate exercise, at first walks on the level, and then gentle ascents, and later on skating, but was forbidden tobogganing and lawn tennis. Cod-liver oil and tonics were persevered with. The pulse and respiration. were 94 and 22 respectively on arrival at St. Moritz, and gradually fell to normal.

May 27th, 1885.-Has just returned and looks well browned and much fatter. Has gained nine pounds, weighing now 9 st. 3 lbs. Cough and expectoration slight. No bacilli found in sputum. Chest expands well in upper portions and appears to have increased specially in lower part.

Measurements at level of second rib : Right side sixteen and an half inches, left side fifteen and a half inches.

Hyper-resonance over the whole chest. Curious band-box 
sound on percussion under right clavicle, where indistinct cavernous sounds are still audible with some crepitation. On left side no crepitation, but harsh breathing with dry crackle everywhere. Ordered to pass a second winter in the Alps.

June 3rd, 1886.-Wintered at Davos, gaining much strength. Was allowed by Dr. Ruedi to skate and toboggan, and often ascended the Schatz Alp, but took no cod-liver oil and lost some weight (about four pounds), nevertheless she appears wiry and looks the picture of health. No cough or expectoration. No band-box sound, no cavernous sounds or crepitation anywhere, but some slight collapse under right clavicle; harsh breathing everywhere.

In 1888 Miss $\mathrm{K}$ - continues quite well.

CASE 2.-Mr. C—, æt. 20, first seen September 8th, 1885. His father and one brother died of consumption. He had had a cough for six years, accompanied by loss of flesh and occasional night sweats, and had voyaged to South Australia and back without benefit.

Dulness and flattening of the upper half right front chest, some dulness and crepitation in scapular region, dulness and flattening of upper third left front chest, with tubular sounds in first interspace. Cough very troublesome, and he states that he loses his voice, but the larynx on examination appears quite healthy. Expectoration contains tubercle bacilli.

Chest measurements at level of third rib :-Right side seventeen inches, left side sixteen and a half inches.

Ordered to winter at St. Moritz under the care of Dr. Holland.

May 2nd, 1886.-Improved wonderfully at St. Moritz and soon lost cough and expectoration. Took a fair amount of exercise; weight about the same. Chest measurements show one inch increase in circumference. The whole chest expands well, and there is no flattening anywhere, all dulness and crepitation have disappeared, and resonance is present everywhere, except over cardiac 
and hepatic regions. Prolonged expiration is heard under both clavicles, but otherwise the expiration is harsh throughout.

Mr. C- returned to his studies as medical student, has since completed his education, and still remains in excellent health (1888).

Sex.-The patients were 100 males and 41 females, belonging to the upper and middle classes of society, and therefore to a large degree secured from the reach of want or poverty.

Age.-Their ages at the time of commencing highaltitude treatment are classified in the subjoined table (Table I), which also contains the percentages of each sex and of the whole number.

The average age was for males $27 \cdot 27$ years, females $24 \cdot 46$.

TABLE I.-Showing Ages of 141 Patients at the time of their Residence in High Altitudes.

\begin{tabular}{|c|c|c|c|c|c|c|}
\hline & \multicolumn{2}{|c|}{ Males. } & \multicolumn{2}{|c|}{ Females. } & \multicolumn{2}{|c|}{ Total. } \\
\hline & No. & |Percentage. & No & Percentage & No. & Percentage \\
\hline $\begin{array}{l}10 \text { to } 20 \text { years } \\
20 \text { to } 30 " \\
30 \text { to } 40 " \\
40 \text { to } 50 "\end{array}$ & $\begin{array}{r}14 \\
55 \\
22 \\
9\end{array}$ & $\begin{array}{l}14 . \\
55 \\
22 . \\
9 .\end{array}$ & $\begin{array}{r}9 \\
24 \\
7 \\
1\end{array}$ & $\begin{array}{c}21 \cdot 95 \\
58 \cdot 53 \\
17 \cdot 07 \\
-\end{array}$ & $\begin{array}{l}23 \\
79 \\
29 \\
10\end{array}$ & $\begin{array}{r}16 \cdot 31 \\
56 \cdot 02 \\
20 \cdot 56 \\
7 \cdot 09\end{array}$ \\
\hline Total . & 100 & & 41 & & 141 & \\
\hline
\end{tabular}

It will be seen that by far the greater number of both sexes were between twenty and thirty, only one fifth being between thirty and forty and one sixth under twenty. No less than 56 per cent. were in the twenty to thirty category, 55 per cent. of the males and $58 \frac{1}{2}$ per cent. of the females, and this fact and the average age show that the majority of these patients were 
attacked rather earlier than the average consumptives of the upper classes, but were also brought under treatment earlier.

As appears in most statistics of the kind, more females than males were attacked before twenty, and more males than females after thirty.

Date of first visit.-This in most cases very shortly preceded the patient's leaving England, and as the first patients were sent in 1878, and in increasing numbers in succeeding years, a considerable period, amounting in some cases to eight or nine years, has elapsed since the first sojourn at high altitudes, and the question of the permanence of this treatment can be tested by the afterhistory.

Length of illness.-By this is meant the period intervening between the first symptoms of disease and the commencement of the mountain residence. This varied greatly in length; 56 of the 141 patients had been ill for less than one year, some for only two or three months, others for two, three, four, five, six, seven and eight years, and one had a history of ten years' illness and another a history of twenty years, but the greater number were sent to high altitudes comparatively early, and this is shown by the average length of illness, which for the males was twenty-four months, or two years, and for the females 19.31 months, or rather over one and a half years. The influence of this factor on the results, and also of the age of the patients, will be considered later on.

Family predisposition.-This was known to be present in 62 out of the 141, or in 44 per cent., and 23 cases were specially recommended for mountain treatment on account of the strong hereditary predisposition, these patients having lost one or both parents from consumption and also brothers or sisters, thus affording evidence of the existence of the disease in the same generation. Family predisposition was present in 32 , or 32 per cent., of the males, and in 30 , or 73 per cent., of the females, the voL. LXXI. 
numbers confirming the former conclusions I arrived at :that family predisposition is more potent among females and males.

Hæmoptysis had occurred to a lesser or greater extent in 61 cases, or in 43.26 per cent., a somewhat smaller percentage than that of the 1000 standard cases from the same classes contained in my "Duration of Phthisis" paper, where it was 57 per cent. Four of the cases belonged to the variety called hæmorrhagic phthisis, characterised by attacks of large recurrent hæmoptysis.

History and nature of cases.-Before describing the condition of these patients' lungs, it may be stated that 3 had malformations of the thorax in the form of pigeon breast, 3 had the complications of syphilis with phthisis, 1 had fistula in ano, and 1 strumous disease of the hip, 1 had phthisis and emphysema, 4 had cardiac lesions (1 aortic regurgitant disease, and 3 mitral regurgitant), 2 of these being the result of rheumatic fever. Four patients, as stated above, were instances of hæmorrhagic phthisis, and one was a case of fibroid phthisis, but the result was so unfarorable that no more patients of this category were sent.

The rest of the patients were nearly all cases of chronic pulmonary phthisis, the symptoms and features of which it is hardly necessary to describe, but it is proposed to give a careful account of the state of the lungs, from which a good idea may be formed of the condition of these patients before leaving England. In most of these cases pyrexia was absent, but in 10 it had been present and had subsided shortly before starting. The degree of wasting was in no case very marked, though some patients had lost a stone in the course of their illness.

State of the lungs.-The chief conclusions from the examination of the chest will be found set forth in Table II, which, with a few explanatory additions, will exhibit the principal facts.

Of the 141 patients, 91 , or $64 \frac{1}{2}$ per cent., were in the first stage, or that of tuberculisation ; 50 , or $35 \frac{1}{2}$ per cent., 
TABLE II.-Showing the Influence of High-altitude Climates on the Condition of the Lungs in 141 cases of Consumption.

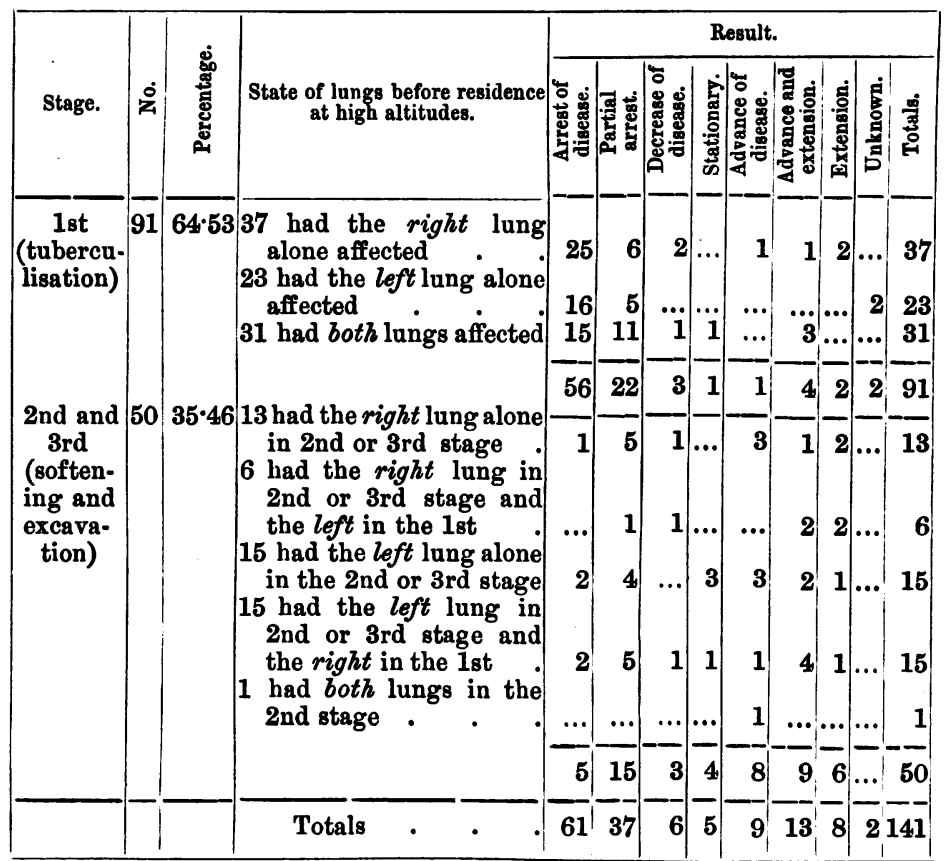

In 53 of the 141 patients both lungs were affected, $i . e$. in 37.58 per cent. In 88 , or 62.41 , one lung was attacked, the right in 50 , or 35.46 per cent., and the left in 38 , or in 27 per cent.

Results.

Per cent.

(Unknowns excluded.)

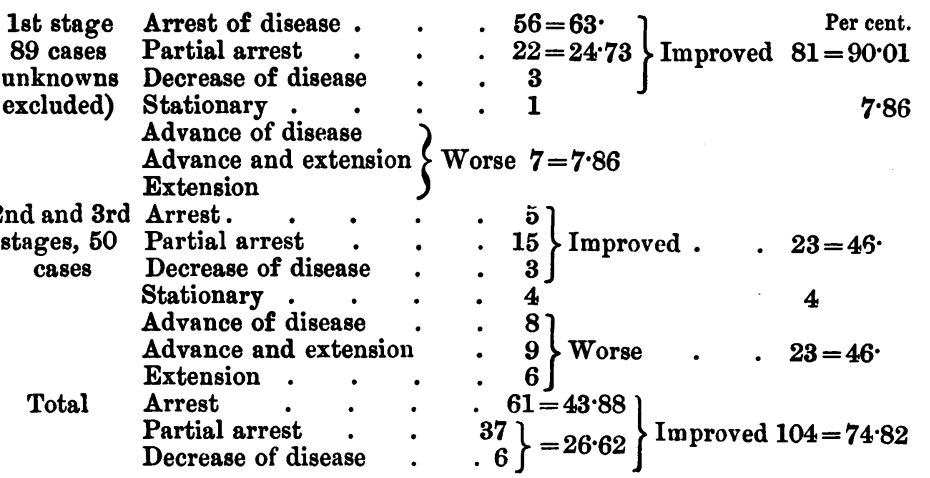




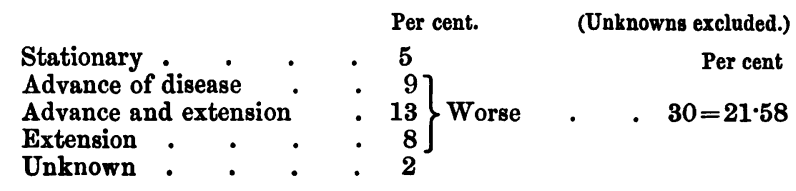

were in the second and third stages, or those of softening and excavation. As regards unilateral and bilateral affections, 88, or 62 per cent., had one lung affected, the right in 50 , or $35 \frac{1}{2}$ per cent., and the left in 38 , or in 27 per cent., and 53, or $37 \frac{1}{2}$ per cent., had both lungs diseased. Taking the first stage, or the tuberculisation cases, we find that one lung was affected in 60 cases, or two thirds, both lungs in 31 , or in one third. The right alone was attacked in 37 and the left alone in 23 , thus confirming the conclusions of my former paper, that the right lung is more liable to tubercular attack than the left. The amount of tuberculisation varied greatly in these 91 cases, and may be classed in three categories.

(1) Cases of incipient phthisis, where one or both apices were involved.

(2) Cases where tuberculisation had affected the whole upper lobe of one or both lungs.

(3) Cases where the consolidation was more extensive, and somewhat scattered in distribution, involving either portions of both lungs or else the whole of one lung. ${ }^{1}$

It was found that among the 91 first-stage cases, 75 , or $82 \frac{1}{2}$ per cent., presented a considerable extent of consolidation, while only 16 , or $17 \frac{1}{2}$ per cent., were instances of what may be called incipient phthisis, with only apical lesions, and attention is specially drawn to this feature.

1 It is possible that this category may include a few cases of old contracted cavities of limited size, especially where the history of symptoms is of some length, but efforts have been made to eliminate these by careful auscultation and measuration of the chest, as well as, whenever possible, by sputum examination; should any remain they would not increase but diminish the favorable character of the cases. 
Of the 50 cases of softening and excavation, 8 were instances of softening, where breaking down of the lung was proceeding, 7 of one apex, and 1 of both apices; and 42 of excavation, where as a rule this process was already accomplished. As these cases can with difficulty be separated, it has been thought advisable to place them together under the head of excavation. Of the whole number of 50 cases, 28 had excavation of one lung, and the opposite one free from disease, 21 had excavation of one lung and the opposite one tuberculised to a more or less extent.

In one case both lungs were undergoing softening. The right lung was the seat of softening or excavation in 19 and the left in 30 , thus confirming the conclusion arrived at in my paper on the "Duration of Phthisis" in vol. liv of the 'Transactions' of this Society, that the left lung is more liable to excavation than the right.

The size of the cavities in these cases varied, but the excavation seldom extended beyond the upper lobe of one lung.

In many of the unilateral cases there was also tuberculisation of the lower lobe or lobes. In two patients one lung was the seat of two or more scattered cavities, and in two others the cavities were basic but still unmistakably tubercular, and in several of the bilateral cases where one lung was the seat of excavation, the middle or lower lobe of the opposite one was the seat of tuberculisation, indicating that the spread of disease had taken place from re-inhaled sputum into the bronchi supplying these lobes.

It may be noted that the greater part of the thirdstage cases were cases of single cavity with limitation of the disease to one lung, the proportion being as 28 to 22 , or nearly as 4 to 3 , and this no doubt exercised a powerful influence on the future of these patients.

Tubercle bacilli in the sputum.-A large proportion of these patients were sent to the mountains before the methods of bacillus staining had come into use. Dr. Ruedi of Davos, Dr. Holland of St. Moritz and I have 
examined the sputum in 54 cases. Tubercle bacilli were detected in 49 of these and were absent in 5 ; in 16 they were abundant.

In some of the patients a number of successive observations were made, but they are neither numerous nor complete enough to draw deductions from. In a certain number the bacilli disappeared from the sputum during mountain residence. No attempt will be made in this paper to determine the exact influence of the mountain atmosphere on the parasite, but a simple statement is made of the result of the testings.

Medicine and diet.-These patients were treated with cod-liver oil and various tonics, and with such other measures as were required for urgent symptoms or intercurrent affections, but the cod-liver oil was not so resolutely persevered with, as in my home climate cases, partly, I have no doubt, because most of the patients felt, after a time, so well, as to deem themselves independent of medicine.

The diet was the usual one of Swiss hotels of three meals a day with meat twice and sometimes thrice daily, and in addition the patients generally took one pint of milk a day. Stimulants in the form of claret and Vältelliner wine were generally made use of.

\section{Length of Residence at High Altitudes.}

The tables show that collectively 141 patients spent 160 years at high altitudes, giving an average of 1 year 1.67 months per patient.

We also find that of the 141 patients 81 passed eightyfive years eleven months at Davos, giving an average of a little over one year for each at that health station; that 59 spent forty years six months at St. Moritz, giving an average of 8.23 months, and that 2 patients passed three and ten months respectively at Wiesen; that 4 patients resided during nine, five and a half, two and a quarter, and half a year respectively alternately at Davos and in 
the Engadine, practically never quitting high altitudes, and that 4 patients lived at the Maloja, 3 for six months each and 1 for three months. Turning to America, we find that 2 consumptives resided in Colorado, each at altitudes varying from 6000 to 9000 feet, for periods of three years. Lastly, we see that 2 patients tried life in the South African Highlands at elevations of from 4000 to 6000 feet, one for six years, and the other for two years.

Now, this average length of residence at high altitudes of 1 year $1 \frac{1}{2}$ months is somewhat deceptive, and appears to be largely due to the presence in the statistics of a comparatively limited number of patients who resided for several years in the mountains, some four, five, six, and nine years respectively, remaining there often after arrest of disease had taken place, for reasons of preference or precaution. If we deduct the patients who spent one year or upwards in these regions, we find that the remaining 92 patients passed 49.9 years, giving an average of $6 \cdot 22$ months, $i . e$. practically equal to one winter.

It will be noted that 19 spent from two to three and a half months only, and these were summer months and not winter.

The majority of the patients passed the winter months at Davos or in the Engadine, and a smaller number extended their stay into the summer, leaving the heights only during the snow-melting, and some passed a second winter and even a third. Before proceeding to the results accruing from this treatment, let us briefly allude to some of the climatic features of the above-mentioned health resorts, and consider the kind of life the invalids passed during their stay in them.

It will be obvious that in our list of stations there is considerable difference of climates, all agreeing in the peculiarity of elevation above the sea level. Colorado has a higher mean temperature than the Grisons, and the South African Highlands of the Orange Free State and Transvaal have a still higher record. As the majority of the patients now under consideration frequented Davos 
and the Engadine, it may not be out of place to say a few words on the climate of the Alpine high-altitude stations generally, which will apply equally to Davos (5200 feet), Wiesen (4.770 feet), St. Moritz (6090 feet), and Maloja (5941 feet). As the most typical, we will select the winter climate, and it is moreover at this season that, having shaken off the impurities due to dust and tourists, this region assumes its white robe of snow and settles down into the wholesome life of a well-regulated health resort, where the food, habits, and the form and amount of exercise of the invalids are under the strict supervision of the medical attendant. The carrying out of this régime is facilitated by the comparative isolation of the valleys, and the absence of many of the attractions of the southern resorts. The patients repair to the Grisons in October, generally before the large snowfall takes place, in order to arrive at their destination on wheels and not in sleighs. They then spend five to six months at the chosen station, being in the open air as much as possible during the hours of sunshine, and retire to their hotels at sunset only. The form of exercise to be used is limited by the strength of the patient and arranged on a graduated scale, commencing with skating and walking on the level and up moderate heights, or advancing to tobogganing-of which, not the swift descent, but the slow and gradual ascent of the snow slope, dragging the toboggan, is the beneficial part-and in time arriving at mountain climbing and short walking tours.

During the first six weeks or two months the pulse and respiration are quickened, and the patient often complains of shortness of breath, but gradually expansion of the lungs and the consequent widening of the chest takes place, which ladies recognise'as necessitating certain adjustments of stays and dresses, and both pulse- and respiration-rate fall to normal and sometimes even below. It is not uncommon for fresh arrivals, and especially elderly people, to complain of sleeplessness, but this generally passes off in about ten days. 
The climate is cold, with sufficient sunshine to admit of sitting out of doors. In the sunshine the heat is as great as-sometimes greater than-on the shores of the Mediterranean, the solar radiation thermometer showing $130^{\circ} \mathrm{F}$., while in the shade it almost always freezes, and the mean temperature for the winter months varies from $26^{\circ} \mathrm{F}$. to $30^{\circ} \mathrm{F}$. At night the temperature falls to far below the freezing point and sometimes to $24^{\circ}$ C. $;^{1}$ and yet patients sleep with windows open with impunity.

The range of temperature between the mean maximum in the shade by day and the mean maximum in the shade by night amounts to $22^{\circ} \mathrm{F}$. As might be expected with so cold an atmosphere, it is very dry; it is also remarkably still.

When snow-melting commences, which is generally at the end of March or the beginning of April, the sloppy condition of the roads and paths renders a descent to a lower level desirable; though, owing to rapid evaporation, the hygrometer indicates only a slight increase of humidity; and the patients then move to places of an altitude of from 2000 to 3000 feet, such as Thusis, Ragaz or Seewis, Gais, or Weissbad, and afterwards either return to the mountains, or travel to England, as the case may be. In some years, when the snowfall is not heary, the melting is not sufficient to require patients to leave, and they remain at mountain stations continuously.

The characteristic elements of Alpine climates seem to be-

1. Diminished barometric pressure and consequent rarefaction of the atmosphere.

2. Diathermancy of the air, or the increased facility by which the sun's rays are transmitted through the attenuated air. This, according to Dr. Denison, causes an increase in the difference between the sun and shade temperatures of $1^{\circ} \mathrm{F}$. for every rise of 235 feet.

3. Dryness of the air, owing chiefly to the low tempe-

I See 'Davoser Blätter,' Jan. 14th, 1888. 
rature and consequent comparative absence of fog and mist.

4. Abserice of strong currents.

5. Aseptic character of the air and freedom from organic germs.

The climate of Colorado has most of the above attributes, and in addition to this, owing to the higher mean temperature, the snow-melting does not take place on such a scale as to render a descent to lower levels necessary ; and consequently patients remain there all the year round, camping out in the summer, and they are also less limited in their walks and excursions in winter. The same may still more strongly be urged on behalf of the South African Highlands, and here the life in the open air and on the trek, sleeping by night in waggons and shooting game by day, is exceedingly beneficial and has been the means of arresting disease in many patients, and one of these is tabulated among the present 141 cases.

General results.-We will now consider the results of the high-altitude treatment on these 141 consumptives, which are described under the headings "general" and "local," general referring to the general health, vigour and weight, and to the main symptoms, including cough and expectoration, and local including only the results of the examination of the lungs.

Under the head of general results are five categories : 1. Cured. 2. Greatly improved. 3. Improved. 4. Stationary. 5. Deteriorated or Worse.

By cured I mean complete restoration to health, with the disappearance of all symptoms of disease.

$\begin{array}{lrlc} & & & \begin{array}{c}\text { Percentages. } \\ \text { Cured }\end{array} \\ \text { Greatly improved } & 42 & \ldots & 41 \cdot 13 \\ \text { Improved } & 16 & \ldots & 29 \cdot 78 \\ \text { Stationary } & 1 & \ldots & 11 \cdot 34 \\ \text { Worse } & 24 & \ldots & 17 \cdot 02\end{array}$


Five patients died during the mountain residence, and 17 more on their return to their homes, after intervals of from a few weeks to nearly three years.

Most of the deaths are included in the deteriorated class, but the single stationary case also deteriorated in the winter following, and gradually becoming worse died two and a half years after leaving Davos; while 3 of those who improved at high altitudes relapsed afterwards and died at intervals of from two to three years after their mountain treatment. One of these, a young lady of exceedingly consumptive family history, with disease at the left apex, who passed one winter at Davos, lost apparently all symptoms and nearly all signs of disease in her chest. She then married a gentleman far advanced in consumption and went to Colorado and New Mexico, where he succumbed. During his illness he was nursed entirely by her. She returned to England in the following spring with cavities in both lungs and with intestinal ulceration, and she died in the autumn.

The following is a list of the causes of death :

4 died of hæmoptysis.

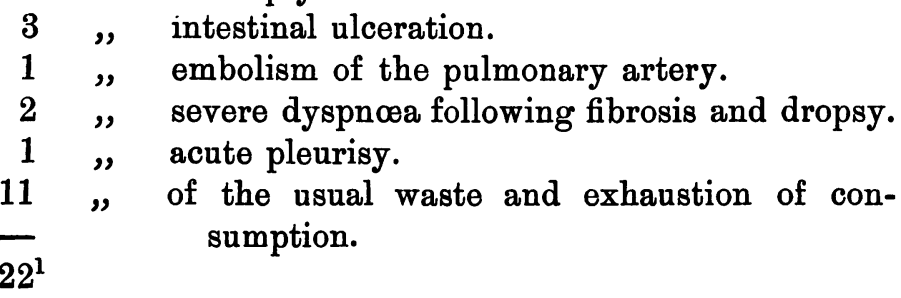

This is a list of the ascertained deaths among the 141, and we have news of all the rest, with very few exceptions, up to present date, so it is only possible that one or two deaths could have occurred among those few exceptions who have been lost sight of.

This mortality of $22,{ }^{1}$ or $15 \cdot 60$ per cent., spread as it is over ten years, is satisfactory.

1 Three patients have died since the reading of this paper, raising the number of deaths from nineteen to twenty-two. 
When we turn to the "cured," the result of 58 , or $41 \cdot 13$ per cent., attaining to this condition is remarkable. 'The number of "greatly improved" reaches 40 , or 28 per cent., and if we bracket "cured," "greatly improved," and "improved" together, we arrive at a total of $116 \mathrm{im}$ proved, or no less than $82 \cdot 25$ per cent., a striking figure considering that 50 cases of softening and excavation are included in the list. The "worse" class number 24, or 17 per cent.

The general appearance of the "improved" class is that of bronzed vigorous individuals, with remarkable walking powers, and among the cures it is not uncommon to find men who can walk thirty, and women who can walk fifteen and twenty miles a day, and can ascend snowpeaks. The appearance of the whole of the "improved" class leaves nothing to be desired, though of course they will not all stand great tests of endurance.

Weights.-The weight of 131 patients was registered, with the following result :

\begin{tabular}{|c|c|c|c|}
\hline & & & Percentages \\
\hline Gained weight & 96 & & $73 \cdot 28$ \\
\hline Stationary & 14 & ... & $10 \cdot 68$ \\
\hline Lost weight & 21 & .. & $16 \cdot 03$ \\
\hline
\end{tabular}

This is fair, considering that the diet, though good, is not so nutritious as the English food, and the amount of exercise taken is very large, consequently the tissue waste must be great.

Dr. Holland, of St. Moritz, drew my attention, during my last visit in winter to that health resort, to the fact that some cases of chronic phthisis when there is no fever, when the cough and expectoration are diminishing, and when the patients are apparently going on well, still lose flesh, even to the extent of four or eight pounds, and he attributed it partly to the increased amount of exercise taken and partly to the very dry atmosphere which surrounds them. The dryness of the air has been shown by Mr. Waters to be almost excessive. 
Before considering in detail the local results in these cases, it may be worth while to draw attention to the principal changes in the thorax and lungs during residence at high altitudes, which have been noted by myself and others, and which have been described by me at some length elsewhere. ${ }^{1}$

Briefly they are these :

1. The thorax increases in circumference to the extent of from one to three inches, such increase taking place in the antero-posterior, the lateral, and sometimes in the vertical directions, and at various levels, but more commonly in the upper portions than in the lower. With this is combined increase in respiratory power, as shown by the depth of inspiration and by spirometrical measurements.

2. Greater resonance on percussion. This is noticeable in the chests of healthy persons, but far more so in consumptives, where there have been distinct areas of dulness. The diminution of dulness is almost invariable, and the deepening of the percussion-note, even in the neighbourhood of extensive consolidation, is so marked that one can generally tell from a chest examination if a patient has or has not recently come from high altitudes.

3. The harshness of the inspiratory sound, audible from the apices to the bases of the lungs. This is invariable over the healthy portions of lung tissue, and in the cases of arrested first-stage phthisis it replaces the areas of tubular sound, scattered crepitation, and bronchophony.

4. The substitution of dry for moist sounds, which has long been observed by the medical men practising at high altitudes. This is to be noted not only in the case of cavities, but also where formerly scattered humid crepitation was heard, and apparently no cavity has formed.

The widening of the thorax, the increased force and depth of inspiration, the deepening in the percussion-note,

1 'Transactions of the International Medical Congress, held in London, 1881, 
seem to be due to hypertrophy of the healthy lung tissue, i.e. to such further development as takes place in any organ from fuller and more complete physiological activity, and this is confirmed by these changes being accompanied by a reduction in the respiration-rate, which, unless there be great pulmonary destruction, occurs generally within the second or third months of high-altitude residence.

When genuine hypertrophy cannot take place, by reason of the diseased condition of the pulmonary tissue, and its lack of proper blood supply, vesicular emphysema results, this being formed chiefly around tubercular nodules, caseous masses, and in the neighbourhood of contracting cavities, whose presence it often masks. The emphysema appears to be the chronic local vesicular form well described by Sir William Jenner.

It is not impossible that both hypertrophy and emphysema may coexist in the same lung, the upper lobe being the seat of scattered consolidations surrounded by emphysematous vesicles, and the lower lobe free from disease and having undergone genuine hypertrophy.

After this explanatory statement we will now consider the local results of high-altitude treatment, first defining the terms " arrest," "partial arrest," " decrease of disease," "stationary," "advance of disease," "advance and extension," and "extension," under which headings the results are arranged.

Arrest signifies in the first-stage patients disappearance of all physical signs of disease. This may be so complete that the medical examiner, without referring to his notes, will not know which lung had been attacked.

In softening and excavation cases arrest means entire disappearance of cavernous sounds, and even of signs of consolidation, and nothing to be detected beyond deficiency of expansion, some harsh breathing over the whole side, and tubular breathing or prolonged expiration above the scapula. In some cases not even these signs were present. In other contracted cavity cases there was a 
certain degree of immobility of the side and flattening of the chest wall, combined with hyper-resonance and prolonged expiration sound.

Partial arrest means that though there is evidence of arrest of the disease, still some physical signs remain, indicating generally limited consolidation, or possibly a contracted cavity.

Decrease of disease signifies simply a diminution of the physical signs, either in extent of area or in intensity.

Advance of disease means the process of softening and excavation of tubercular consolidations.

Extension of disease the spread of tuberculisation in one or both lungs.

Advance and extension a combination of these two processes.

Stationary indicates a condition in which there is no diminution in the original lesions, though it does not preclude hypertrophy of portions of the lung or lungs not already attacked.

The local results are fairly shown in Table II, to which a summary is appended. We see here that out of the whole number, in 61 , or nearly 44 per cent., arrest of the disease took place, in 37 , or $26 \frac{1}{2}$ per cent., there was partial arrest, and in 6 decrease of disease ; that in 5 the disease was stationary, in 8 it advanced, in 9 it advanced and extended, and in 8 it extended. Bracketing "arrest," "partial arrest," and " decrease of disease," we arrive at a total of 104 improved, or 74.82 per cent., not so high a percentage as in the general list, which was 82 , but still a very favorable one. Throwing together the " advance," " advance and extension," and "extension," we arrive at 30 , or $21 \frac{1}{2}$ per cent., of "worse." We should note, too, the small number of the stationary class, only 5 , or 3.59 per cent., which indicates that the climatic treatment was by no means negative in its result, but acted powerfully in one or other direction.

Most instructive is the study of the results of the different stages of the disease, for we find that, excluding 
2 " unknowns," of 89 in the first stage arrest of disease took place in 56, or 63 per cent., partial arrest in 22, or 24.73 per cent., decrease of disease in 3 , advance in 1 , advance and extension in 4, extension in 2 ; and a stationary condition was maintained in 1, or, in other words, arrest or improvement took place in 81 out of the 89 , or in 91.01 per cent., and deterioration ("worse") in 7 only, or in 7.86 per cent.

With reference to the question of one or both lungs being attacked, and its bearing on the prognosis, we find that the 58 cases (unknowns deducted) of unilateral affection gave 41 cases, or 70.68 per cent. of arrest, 11 of partial arrest (18.96 per cent.), 2 of decrease of disease, and 4 of "advance," "advance and extension," and " extension," $i$.e. 44 or $92 \cdot 11$ per cent. of "improved," and only 4 deteriorations, or 6.89 per cent., whereas of 31 cases of double affection 15 were "arrests" (48.38 per cent.), 11 (35.48 per cent.) were "partial arrests," 1 showed "decrease," against 3 "advance" of disease, "advance and extension," and "extension;" also 1 stationary, making 28 cures and improved (90.32 per cent.) and only 3 deteriorations ( 9 per cent.). The difference in the first-stage class between the total numbers of the improved in the unilateral and bilateral cases is not very striking, indicating that great progress towards arrest was made, even in cases of double affection, but when we compare the relative numbers in the "arrest" class we find the true significance of the double affection, for these show us that whereas this latter class counted 48 per cent. of "arrests," the single lung cases counted 70.68 per cent.

As to the relative chances of the two lungs in the race for recovery, it would appear that the left lung has rather the best of it, as out of 21 left-sided cases, "unknowns" having been excluded, all were improved (16 arrests and 5 partial arrests), whereas among the right-sided ones 37, or 89 per cent., had improved, including 25 arrests $(67 \cdot 56$ per cent.). 
Passing to the second-and third-stage patients we see that out of 50 cases 5 were instances of arrest, 15 of partial arrest, and 3 of decrease of disease. In 8 the disease advanced, in 9 it advanced and extended, and in 6 it extended; in 4 it remained stationary. This gives 23 cases ( 46 per cent.) of improved, including 5 arrests, with 23 instances of deterioration, $i . e$. equal numbers, or nearly half of the total number, either gained or lost ground. This is a good result when we remember the large number (22) of double affection cases, but it points very decidedly to the different expectations to be held out in cases of consolidation and of excavation respectively, for be it remembered that in the first stage the relative numbers were : improved 91.01 per cent., and deteriorated $7 \cdot 86$ per cent.

Further analysing the returns of the cavity cases we see that the 28 instances of single cavity yielded better results than where both lungs were affected, the single cavities giving three cases of "arrest," 9 of "partial arrest," and 1 of decrease of disease, against 12 " deteriorations " and 3 "stationary," or, putting it into percentages, "improved" 46.42 per cent., "worse" 42.8 per cent., whereas the double affection cases yielded 2 arrests, 6 partial arrests, and 2 decrease of disease against 11 deteriorations and 1 stationary, or "improved" 45.45 per cent., "worse" 50 per cent., a result which gives the advantage to the single cavity cases.

With regard to the relative prognosis of the two lungs after excavation has taken place these cases furnish the following: 19 right "single" and "double affection" cases yielded 1 arrest, 6 partial arrests, 1 decrease of disease, i.e. 9 improved (nearly half) against 10 deteriorations.

The 30 left " single" and " double affections" of cavity cases give 4 arrests, 9 partial arrests, 1 decrease of disease, i.e. 14 improved against 12 deteriorations, 4 being stationary. Placing it in percentages : 


$\begin{array}{lllc} & \text { Improved. } & \text { Worse. } & \text { Stationary. } \\ \text { Right lung cavities } & 47 \cdot 37 & 52 \cdot 53 & \\ \text { Left „, , } & 46 \cdot 67 & 40 & 13\end{array}$

The difference of result here shown is not very marked, but it indicates that the left lung cases showed less tendency to change, either for the better or the worse, than the right.

To sum up the local results :

In the 141 consumptives improvement, greater or less, took place in 74.82 per cent., arrest of disease in nearly 44 per cent., and deterioration in $21 \frac{1}{2}$ per cent.

Among the first-stage cases there was improvement in 91 per cent. and arrest of disease in 63 per cent., with deterioration in $7 \frac{1}{2}$ per cent.

Cases of unilateral first-stage disease yielded 92 per cent. "improved," including $70 \frac{1}{2}$ per cent. of "arrests," whereas cases of bilateral affection of the first stage give 87 per cent. " improved" with $48 \frac{1}{3}$ per cent. of " arrests."

In the second-and third-stage cases there was improvement to a greater or less extent in 46 per cent., arrests in 10 per cent., and deterioration in 46 per cent.

Single cavity cases gave better results than cavity cases with the opposite lung involved; and left lung cavities showed less tendency to change, either for better or worse, than the right ones. ${ }^{1}$

1 It will be of interest here to refer to Dr. Denison's statistics of 202 consumptives residing in Colorado at altitudes of 5000 feet and upwards. They consisted of 148 males and 54 females, and had an average history of two years' illness before arriving at Colorado; 37 per cent. were in the first stage and 63 per cent. in the second and third stages; 56 per cent. had both lungs affected. The average stay in Colorado was one year and nine months.

As compared with my cases these patients"included more second- and thirdstage cases and examples of double affection, but their average stay at high altitudes was far longer; 69 per cent. were " much improved" and " slightly improved," 12 per cent. showed "favorable resistance," which equals, I suppose, "stationary," and 28 per cent. showed "extension or advance of disease ;" 20 per cent. of the patients died.

A further study of the details shorrs (1) the great number of the improved to be among the first-stage cases; (2) that the number of stationary cases in the total was small; (3) that the larger proportion of "deteriorated" came 
Chest measurements.-These were carried out with Hare's measuring tape at various levels, those generally selected being that of the third rib, the mammary level, and the level of the ensiform cartilage. In some cases calipers measurements were used, and in a good many tracings were made by the aid of the cyrtometer.

It is not proposed to give the whole details of this work as the subject was discussed in reference to a smaller number of patients by me elsewhere, ${ }^{1}$ and the present observations confirm the former ones.

Measurements were taken in 86 of the 141 patients, and in 83 , or in $96 \frac{1}{2}$ per cent., considerable increase in chest circumference was found to have taken place. In 3 no increase occurred. In one of these there had been pleurisy on both sides of the chest, and there were probably extensive adhesions with some fibrosis; in another both lungs were affected, and a cavity existed in the left lower lobe during the mountain residence. Another cavity then formed in the upper right lobe, and some contraction of one side of the chest took place, but marked signs of emphysema were detected on the opposite side.

In these two cases the measures on return were identical with those taken before departure. In the third case the measures were not as accurately taken as I could desire. With these three exceptions expansion of the thorax was noted in all the cases where measurements were taken. The largest amount recorded was three and a half inches at the third rib level.

\section{Influence of Sex.}

Did the males reap more benefit than the females from the mountain climate? The natural inference would be

from the cavity cases. Dr. Denison's statistics, though wanting in many details, such as the record of the extent of lung mischief-and not so favorable in results as mine-support the conclusions arrived at above, and are the more interesting as furnishing large evidence of the same healing influence being turned to account in the Rocky Mountains as has been done in the Alps.

1 ' Trans. International Medical Congress, London, 1881.' 
that the sex, which was able to take the largest amount of outdoor exercise, would profit most.

On comparing the extent of disease present in the patients of each sex, I cannot detect any material difference; 35 per cent. of the males were in the excavation stage, and $36 \frac{1}{2}$ per cent. of the females; 37 per cent. of the males had both lungs affected, and 31.70 per cent. of the females.

Turning to the general results we find that males counted 43 " cured," or 43 per cent., and 83 " improved," to 17 , or 41.46 per cent., "cured" among the females, with 33 , or 80.43 per cent., " improved." The results of the two sexes may be considered even, the slight difference of 3 per cent. being explained by the slightly larger number of cavity cases among the women.

\section{Influence of Age at Time of commencing Alpine Residence.}

A reference to Table $I$ shows us that the great majority of the patients were between twenty and thirty when they commenced high-altitude treatment, only one fifth being under twenty, and about one fourth over thirty.

The average has been taken of each sex in each category of the general results with the following conclusions :

$\begin{array}{cccc}\text { Average age of "cured " } & \begin{array}{c}\text { Males. } \\ 23 \cdot 8\end{array} & \begin{array}{c}\text { Females. } \\ 24.9\end{array} \\ \text { " of " greatly improved" } & & \\ \text { " } \quad \text { and "improved" } & 29 \cdot 7 & 25 \cdot 4 \\ \text { " of " deteriorated" } & 30 & 19 \cdot 6\end{array}$

The range of age among the males was somewhat wider than among the females, and this may account for the difference between the ages of the "cured" and "improved" among the former. The contrast of the ages in the "deteriorated" is most striking, and leads us naturally to the conclusion that the climate does not so well suit females under twenty or males over thirty, in fact it would appear that the younger a man is the more likely 
is his system to benefit by the expanding and bracing influence of mountain climates, and on the other hand, for a woman to be similarly benefited, her frame must have attained to that standard of development and circulatory power which enables her system to withstand the great cold.

Influence of Family Predisposition on the Results of Mountain Treatment.

Did the cases in which family predisposition was present fare worse than the rest? In 62 this feature was traced, and in 23 it was strongly present. These 62 yielded 28 cures (including 10 of the most marked examples of predisposition), 17 greatly improved, 6 improved, 1 stationary, and 10 deteriorated. Now, placing these into percentages and comparing them with the total results, we get:

Whole number of cases. Cases with family predisposition.

Cured Per. cent. Per cent.

$\left.\begin{array}{l}\text { Cured } \\ \text { Greatly improved } \\ \text { Improved }\end{array}\right\} 82 \cdot 25$

Deteriorated

$17 \cdot 02$

$82 \cdot 25$

$16 \cdot 12$

Thus it appears that this element exercised no check on the favorable progress of the case, and that these patients did as well as the rest; and as no less than 17 of the 23 cases of marked predisposition improved, we may fairly claim the mountain climate as a powerful antidote to this terrible and often fatal influence in cases of phthisis.

Influence of Length of Illness.

As we have stated before, these patients gave a history of symptoms varying from a few months to several years before commencing mountain residence, and an attempt has been made in the annexed table (Table III) to determine how far the length of the illness influenced the results. The average length of history was for the males two years, and for the females $19 \cdot 31$ months. The patients are divided into 
four categories according to the duration of the symptoms, and it will be noted that more than half these were of less than one year's duration. We see that the number of deteriorated (worse) steadily increases with the long standing of the disease.

TABLE III.-Showing Influence of Duration of Illness on the Result of High Altitudes in Treatment.

\begin{tabular}{|c|c|c|c|c|c|c|c|}
\hline 范 & Duration of illness. & 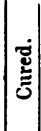 & $\begin{array}{c}\text { Greatly } \\
\text { improved } \\
\text { and } \\
\text { improved. }\end{array}$ & 离 & 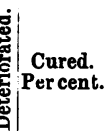 & $\begin{array}{l}\text { Improved. } \\
\text { Per cent. }\end{array}$ & $\begin{array}{c}\text { Dete- } \\
\text { riorated. } \\
\text { Per cent. }\end{array}$ \\
\hline $\begin{array}{l}42 \\
40 \\
19 \\
40\end{array}$ & $\begin{array}{l}6 \text { months and under } \\
6 \text { to } 12 \text { months (inclusive) } \\
\text { From } 1 \text { to } 2 \text { years } \\
\text { Periods exceeding } 2 \text { years }\end{array}$ & $\mid \begin{array}{r}21 \\
15 \\
8 \\
14\end{array}$ & $\begin{array}{r}16 \\
18 \\
7 \\
17\end{array}$ & $\begin{array}{l}-1 \\
-1 \\
- \\
- \\
4 \\
9\end{array}$ & \begin{tabular}{l|l|}
$\mathbf{5}$ & $50 \cdot 00$ \\
6 & $37 \cdot 50$ \\
4 & $42 \cdot 10$ \\
9 & $35 \cdot$
\end{tabular} & $\begin{array}{l}38 \cdot 09 \\
45 \cdot 00 \\
36 \cdot 89 \\
42 \cdot 5\end{array}$ & $\begin{array}{l}11 \cdot 90 \\
15 \cdot 00 \\
21 \cdot 05 \\
22 \cdot 5\end{array}$ \\
\hline
\end{tabular}

The patients with a history of six months and under, show 11.9 per cent. of worse, those with histories exceeding two years show $22 \frac{1}{2}$ per cent., nearly double the former.

Those in the first category claim 50 per cent. of cures, against 35 per cent. in the last.

The improved class does not present such a contrast, and it is evident that the cases of older standing, while not capable of counting so many complete cures, are able to display considerable improvement.

The table warrants us in concluding that mountain climates are most effective in arresting phthisis where the disease is of recent standing, ${ }^{1}$ but they are also beneficial in cases where the disease has existed for a longer time.

\section{Influence of Mountain Treatment on Hæmoptysis.}

Sixty-one of these patients had had hæmoptysis previous to their residence in high altitudes; only 6 spat blood

1 This agrees with Dr. Denison's conclusion - "The resort to a high-altitude climate by a consumptive gives a proportionately better result the earlier it is undertaken." 
during their mountain sojourn; in one case it was fatal and in 3 others, profuse. In 2 patients hæmoptysis occurred while descending from Davos to lower levels. Four of the patients were examples of hæmorrhagic phthisis, and 2 of these during their stay in the mountains were quite exempt from hæmoptysis; the other 2 had attacks, but less severe and less frequent than they had had formerly at low levels. ${ }^{1} \quad$ The above evidence points to hæmoptysis being less common at high altitudes than at low levels, but the climate does not entirely preclude its occurrence.

We believe the facts contained in this paper warrant the following conclusions :

1. That prolonged residence at high altitudes produces great improvement in the majority of consumptive patients, and complete arrest of the disease in a considerable proportion, such arrests being of a more or less permanent character.

2. That in order to secure these advantages patients must be free from pyrexia and all acute symptoms, and must possess sufficient lung surface to adequately carry on the process of respiration in the rarefied atmosphere.

3 . That in the cases of unilateral tubercular consolidation more or less extensive improvement occurred in 92 per cent. and complete arrest in $70 \frac{1}{2}$ per cent., and that the left lung showed greater tendency towards such arrest of disease than the right lung.

4. That in cases of bilateral tubercular consolidation there was improvement in 87.09 per cent. and arrest in 48.38 per cent.

5. That patients in the stage of softening and excavation (the cavity or cavities being limited to one lung)

1 Dr. Denison holds "that the advantages of high altitudes are pre-eminently for hæmorrhagic cases in the first stage, while hæmorrhagic cases with excavations, especially if the bleeding has been recent and softening is in progress, should be interdicted from high elevations." I have known, however, cavity cases, with formerly large and recurrent hæmoptysis, perfectly recover at high altitudes, and remain free from hæmorrhage. 
showed improvement in about half their whole number and deterioration in the same proportion, the arrests not exceeding 10 per cent.

6. That single cavity cases, where the opposite lung was free from disease, reaped more advantage than cavity cases with double affection, and that the left-sided cavities showed less tendency to extension or advance of disease than the right-sided ones.

7. That the influence of the climate seems to promote a change in the lungs, whether of a curative or destructive character, and to oppose quiescence.

8. That residence at high altitudes causes enlargement of the thorax, hypertrophy of the healthy lung tissue, and the development of pulmonary emphysema around the tubercular lesions, and that this expansion of the chest is accompanied by a diminution of the pulse- and respirationrate.

9. That it is probable that the arrest of consumptive disease is partly owing to the pressure exercised on the tubercular masses by the increasing bulk of the surrounding tissue, which by emptying the blood-vessels of the part produces caseation and cretification of the tubercle.

10. That the above local changes are accompanied by general improvement, shown in the cessation of all symptoms and the gain of weight, colour, muscular, respiratory, and circulatory power.

11. That consumptives of both sexes benefit equally by mountain residence, but that the age of the patient exercises considerable influence on the result, females under twenty and males over forty reaping least advantage from such residence. Between 20 and 30 both sexes showed great improvement.

12. That the high-altitude treatment seemed to be specially adapted in cases where hereditary and family predisposition was present, and to exercise a distinctly counteracting influence over the development of the disease.

13. That the climate is beneficial in cases of hæmor- 
rhagic phthisis, and that hæmoptysis is of rare occurrence at the mountain stations.

14. That mountain climates are most effective in arresting phthisis when the disease is of recent date, but they are also beneficial in cases of longer standing.

15. That the special effects of high-altitude residence on the healthy and sick are common to all mountain ranges of elevations of from 5000 feet and upwards, and have been observed in the Alps, the Rocky Mountains, the Andes, the Himalayas, and the Sonth African Highlands.

16. That to ensure the full advantages of high-altitude residence a period of at least six months is necessary, and in cases of long standing and of extensive lesions one or two years are often requisite to produce arrest of the disease. That nevertheless arrest of the disease sometimes takes place after so short a period as two or three months' residence, and was noted in 6 per cent. of the patients.

17. That in addition to the above examples, mountain climates are beneficial in (1) cases of imperfect thoracic and pulmonary development, (2) in chronic pneumonia without bronchiectasis, (3) chronic pleurisy, where the lung does not expand after removal of the fluid, (4) spasmodic asthma without much emphysema, (5) and in anæmia.

18. That they are contra-indicated in the following conditions: (1) Phthisis with double cavities, with or without pyrexia. (2) Cases of phthisis where the pulmonary area at low levels hardly suffices for respiratory purposes. (3) Catarrhal phthisis and laryngeal phthisis. (4) Erethric phthisis, or phthisis where there is great irritability of the nervous system. (5) Emphysema. (6) Chronic bronchitis and bronchiectasis. (7) Diseases of the heart and great vessels. (8) Affections of the brain and spinal cord and conditions of hyper-sensibility of the nervous system; and (9) where the patients are of advanced age, and where they are too feeble to take exercise. 
In conclusion, I must acknowledge kind help from Dr. Ruedi of Davos, Dr. Holland of St. Moritz, and Dr. Wise of Maloja, in supplying information about the cases which had been entrusted to their charge.

Postscript, July, 1888.-In the discussion which followed it was urged that results equal to those of the high-altitude treatment of consumption had been obtained at lower levels by special attention to food, air supply, exercise, and medicine ; and Dr. Dettweiler's statistics of cases of phthisis treated in his establishment at Falkenstein, in the Taunus, were instanced as examples. At my request Dr. Dettweiler kindly furnished me with a copy of his paper, ${ }^{1}$ from which I extract the following facts : "Out of 1022 cases of phthisis, 132 quitted Falkenstein as "complete cures" and 110 as " relative cures," with still some symptoms and physical signs of disease. This yields about 13 per cent. "cures" and 10 per cent. " relative cures," and a total of $24 \cdot 2$ per cent. greatly improved. Dr. Dettweiler's cases, as far as they are given, do not appear to differ much from mine, and are certainly not more unfavorable, and the average length of time passed at the health resort is about the same in both sets of cases. But the high-altitude results yield $41 \cdot 13$ per cent. " cures" against Dr. Dettweiler's 13 per cent., and 82.25 per cent. improved (more or less) against Dr. Dettweiler's $24 \cdot 2$ per cent. Even among his "cures," the after-fate of only 98 could be ascertained, which throws some doubt on their right to be regarded as such; 72 were cases of arrest and remained so up to the present date, but 12 had relapsed and recovered, 3 had relapsed and not recovered, and $11 \mathrm{had}$ died. It is needless to say that the high-altitude results need not fear comparison with such statistics.

1 Bericht über zwei und siebzig seit drei bis neun Jahren völlig geheilte Fälle von Lungenschwindsucht, 1886.

(For report of the discussion on this paper, see 'Proceedings of the Royal Medical and Chirurgical Society,' New Series, vol. ii, p. 382.) 